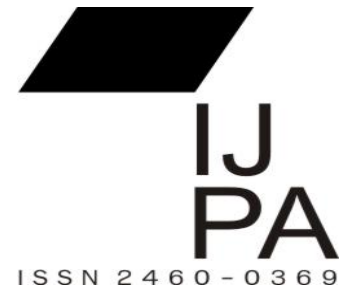

\section{PENGARUH IMPLEMENTASI KEBIJAKAN DAN KOMPETENSI SDM TERHADAP EFEKTIVITAS PENGELOLAAN SAMPAH DI KOTA DEPOK}

\section{Raymundus I Wayan Ray}

\author{
Program Studi Ilmu Administrasi Publik \\ Fakultas Ilmu Ssosial dan Ilmu Politik \\ Universitas 17 Agustus 1945 Jakarta \\ raymundus.ray@uta45jakarta.ac.id
}

Abstract: This study aims to determine the effect of implementation of human resources policies and the competence of the effectiveness of waste management in Depok. The dependent variable in this study is the effectiveness of waste management, while the independent variable in this study is the implementation of human resources policies and competence. The approach used is quantitative analysis, using primary data obtained from questionnaires. Kuisiner distributed to 60 respondents, who are civil servants (PNS) from Depok City Sanitation Department. The results were obtained by partial calculation that the implementation of human resources policies and the competence of positive and significant impact on the effectiveness of waste management. Besides, the implementation of human resources policies and the competence of the results of calculations simultaneously positive and significant impact on the effectiveness of waste management in Depok.

Keywords: Policy Implementation, HR Competence, and Management Effectiveness

\begin{abstract}
Abstrak: Penelitian ini bertujuan untuk mengetahui pengaruh implementasi kebijakan dan kompetensi SDM terhadap efektivitas pengelolaan sampah di Kota Depok. Variabel dependen dalam penelitian ini adalah Efektivitas Pengelolaan Sampah, sedangkan untuk variabel independen dalam penelitian ini adalah Implementasi Kebijakan dan Kompetensi SDM. Pendekatan yang dipergunakan adalah analisis Kuantitatif, dengan menggunakan data primer yang diperoleh dari penyebaran kuisioner. Kuisiner yang disebarkan kepada 60 orang responden, yang merupakan pegawai Negeri Sipil (PNS) dari Dinas Kebersihan Kota Depok. Hasil penelitian diperoleh perhitungan secara parsial bahwa Implementasi Kebijakan dan Kompetensi SDM berpengaruh positif dan signifikan terhadap Efektivitas Pengelolaan Sampah. Disamping itu Implementasi Kebijakan dan Kompetensi SDM dari hasil perhitungan secara simultan berpengaruh positif dan signifikan terhadap Efektivitas Pengelolaan Sampah di Kota Depok.
\end{abstract}

Kata Kunci: Implementasi Kebijakan, Kompetensi SDM, dan Efektivitas Pengelolaan Sampah 


\section{PENDAHULUAN}

Sampah pada dasarnya merupakan suatu bahan yang terbuang atau dibuang dari suatu sumber hasil aktivitas manusia maupun proses-proses alam yang tidak mempunyai nilai ekonomi, bahkan dapat mempunyai nilai yang negatif karena dalam penanganannya, baik untuk membuang atau membersihkannya memerlukan biaya yang cukup besar. Sampah dan pengelolaannya kini menjadi masalah yang kian mendesak di kota-kota di Indonesia, sebab apabila tidak dilakukan penanganan yang baik akan mengakibatkan terjadinya perubahan keseimbangan lingkungan yang merugikan atau tidak diharapkan sehingga dapat mencemari lingkungan, baik terhadap tanah, air dan udara. Oleh karena itu untuk mengatasi masalah pencemaran tersebut diperlukan penanganan dan pengendalian terhadap sampah.

Penanganan dan pengendalian akan menjadi semakin kompleks dan rumit dengan semakin kompleksnya jenis maupun komposisi dari sampah sejalan dengan majunya kebudayaan. Oleh karena itu penanganan sampah di perkotaan relatif lebih rumit dibanding sampah di desa-desa. Masalah yang sering muncul dalam penanganan sampah kota adalah masalah biaya operasional yang tinggi dan semakin sulitnya ruang yang pantas untuk pembuangan. Sebagai akibat biaya operasional yang tinggi, kebanyakan kota-kota di Indonesia hanya mampu mengumpulkan dan membuang sekitar $60 \%$ dari seluruh produksi sampahnya. Untuk mendapatkan tingkat efektifitas dan efisiensi yang tinggi dalam penanganan sampah di kota, maka dalam pengelolaannya harus cukup layak diterapkan yang sekaligus disertai upaya pemanfaatannya sehingga diharapkan mempunyai keuntungan berupa nilai tambah. Untuk mencapai hal tersebut, maka perlu pemilihan cara dan teknologi yang tepat, perlu partisipasi aktif dari masyarakat dari mana sumber sampah berasal dan mungkin perlu dilakukan kerjasama antar lembaga pemerintah yang terkait. Disamping itu juga perlu aspek legal untuk dijadikan pedoman berupa peraturan-peraturan mengenai lingkungan demi menanggulangi pencemaran lingkungan yang diakibatkan oleh sampah.

Untuk mendukung pembangunan Kota Depok yang berkelanjutan dan seiring dengan adanya peraturan -. peraturan baru mengenai Lingkungan Hidup dan Persampahan maka perlu dicari suatu cara pengelolaan sampah secara efektif melalui perencanaan yang matang dan terkendali dalam bentuk pengelolaan secara terpadu. Sehubungan dengan hal tersebut di atas, maka pemerintah Kota Depok telah melakukan kegiatan Penyusunan Rencana Induk Persampahan. Keterbatasan lainnya dalam hal kurangnya alat angkut sampah dan sarana-sarana pendukung akan berdampak pada pelayanan pengolahan sampah. Persentase penduduk yang pengolahan sampahnya dapat dilayani masih minim., maka perlu pemikiran lebih lanjut bagaimana mengurangi jumlah limbah padat dengan 
memanfaatkan kembali limbah padat untuk kepentingan manusia melalui proses daur-ulang, sekaligus sebagai usaha untuk mengurangi pencemaran daratan. Limbah padat yang semula tidak berharga, setelah dimanfaatkan kembali melalui proses daur ulang menjadi bernilai ekonomis.Pemerintah Kota Depok dinilai belum maksimal dalam mengelola sampah termasuk di unit pengolahan sampah (UPS). Berdasarkan fakta di lapangan, UPS hanya mampu mengolah 30 persen sampah dari yang telah ditargetkan. Berdasarkan kajian sebenarnya tempat pembuangan akhir (TPA) Cipayung hanya bisa digunakan sampai 2011. Namun penumpukan sampah terus dilakukan. Sementara pengolahan di UPS hanya mampu mencapai 5-10 m3 sampah per hari. Padahal, sebelumnya pemerintah Kota mentargetkan UPS bisa mengelola sampah sampai $30 \mathrm{~m} 3$ per hari. Sementara untuk membuka lahan TPA baru, membutuhkan proses yang panjang. Hal itu termasuk untuk mendapatkan persetujuan warga di sekitarnya. Selain itu, program Gerakan Memilah sampah di RPJMD dengan target 330 rumah tangga/tahun, juga dinilai kurang efektif. "Kalau dengan jumlah itu sampai kapan seluruh Depok bisa memilah rumah tangga. Satu RT saja bisa mencapai 150 kepala keluarga, dan jumlah rumah tangga terus bertambah seiring meningkatnya populasi,

Upaya Pemkot Depok dalam menyosialisasikan program 3R (Reduce, Reused, Recycle) juga belum maksimal.Tingkat kesadaran masyarakat masih rendah, padahal kalau berhasil maka ini akan mempengaruhi penurunan sampah, setiap harinya hanya 28 persen sampah yang dingkut ke TPA.Jumlah sampah yang dihasilkandi Kota Depok yaitu 4.200 meter3/hari. Namun yang dapat diangkut ke TPA hanya sebanyak $1.200 \mathrm{~m} 3$. Sementara $450 \mathrm{~m} 3$ lainnya diolah di UPS. "Diharapkan sedikitnya 29 persen sampah yang tersisa, dapat diolah oleh masyarakat sendiri dengan konsep $3 \mathrm{R}$. Kompetensi sumber daya manusia untuk pengelolaan sampah sangat mendukung, kerena kalau kompetensi SDM itu rendah, maka efektivitas dalam pengelolaan sampah itu tidak akan sesuai dengan target yang dicapai. Demikian pula implementasi kebijakan harus jelas dan sesuai dengan PERDA : Nomor 5 Tahun 2014. Sumber daya manusia untuk mengangkut sampah juga masih terbatas. Berdasarkan data DKP, tercatat 133 tenaga pesapon yang bekerja untuk menjangkau seluruh wilayah Depok. Padahal di beberapa titik tertentu membutuhkan tenaga ekstra seperti pasar dan ruang publik lainnya. Sementara untuk sarana dan prasarana di DKP tercatat 28 unit gerobak sampah, empat unit motor sampah, dan 14 unit truk pengangkut sampah.

Keberadaan program pengelolaan sampah yang terpadu tidak hanya menyangkut masalah kebersihan dan lingkungan saja, namun juga menyimpan potensi manfaat ekonomi dan sosial. Masuknya unsur teknologi, kompetensi SDM, sistem, hukum, sosial, dan dana dalam suatu program pengelolaan sampah, akan menjadikan sampah tidak lagi diletakkan sebagai sumber masalah, tetapi sebaliknya, dipandang sebagai sumber daya yang dapat diolah dan dikelola untuk 
memberikan manfaat yang besar bagi masyarakat. Manfaat tersebut antara lain adalah menciptakan lapangan kerja dan menghasilkan produk bernilai jual. Potensi nilai ekonomis tersebut merupakan potensi penerimaan yang tidak dapat dikesampingkan dalam upaya menciptakan keberlanjutan program pengelolaan sampah yang terpadu. Selain itu, untuk mengolah sampah tersebut dibutuhkan sejumlah tenaga kerja sehingga nantinya keberadaan program pengolahan sampah akan membuka lapangan kerja khususnya bagi warga di sekitar lokasi pengolahan.

Berbagai upaya dilakukan untuk menangani sampah di Kota Depok. Namun upaya tersebut kerap menimbulkan kendala. Sulitnya mencari lahan untuk Tempat Pembuangan Akhir (TPA), serta sebagian warga Kota Depok yang tidak disiplin dengan membuang sampah seenaknya, membuat wajah Kota Depok semakin jelek dengan tumpukan sampah di sana-sini.Berdasarkan permasalahan tersebut di atas, maka penulis tertarik untuk membahas tentang : Pengaruh Implementasi Kebijakan dan Kompetensi SDM Terhadap Efektivitas Pengolahan Sampah di Kota Depok.Perumusan masalah dalam penelitian ini adalah : 1 . Apakah ada pengaruh implementasi kebijakan terhadap efektivitas pengelolaan sampah di Kota Depok.? 2. Apakah ada pengaruh kompetensi SDM terhadap efektivitas pengelolaan sampah di Kota Depok.?, 3. Apakah ada pengaruh secara simultan implementasi kebijakan dan kompetensi SDM terhadap efiktivitas pengelolaan sampah di Kota Depok.?

\section{TINJAUAN PUSTAKA}

\section{Implementasi Kebijakan}

Dalam menelaah suatu proses kebijakan aspek yang sangat penting yaitu implementasi kebijakan. Hal ini dinyatakan oleh Dunn yang diterjemahkan oleh Samodra (2003:80), dalam bukunya yang berjudul Pengantar Analisis Kebijakan Publik mengemukakan bahwa : "Implementasi kebijakan adalah pelaksanaan dan pengendalian arah tindakan kebijakan sampai dicapainya hasil kebijakan." Hasil yang dicapai dari kebijakan tersebut dapat dilihat setelah kebijakan tersebut diimplementasikan, maka peneliti menegemukakan pengertian pelaksanaan kebijakan yang dikemukakan oleh Van Meter dan Horn yang dikutip oleh Winarno (2008:146) dalam bukunya Kebijakan Publik: Teori dan Proses, bahwa implementasi kebijakan mempunyai pengertian sebagai berikut : Implementasi kebijakan sebagai tindakan-tindakan yang dilakukan oleh individu-individu (atau kelompok-kelompok) pemerintah maupun swasta yang diarahkan untuk mencapai tujuan-tujuan yang telah ditetapkan dalam keputusank-keputusan kebijakan sebelumnya. Pengertian implementasi kebijakan juga dirumuskan oleh Wahab (2008:64) dalam bukunya Analisis Kebijaksanaan dari Formulasi ke Implementasi Kebijaksanaan Negara yang menyebutkan sebagai berikut : Implementasi kebijakan merupakan suatu proses pelaksanaan keputusan kebijakan (biasanya 
dalam bentuk undang-undang, peraturan pemerintah, keputusan peradilan, pemerintah eksekutif, atau dekrit presiden).

Berbicara mengenai kebijakan, maka tidak akan terlepas dari negara atau pemerintah, hal ini karena biasanya kebijakan itu itu dikeluarkan oleh pemerintah atau negara. Dye menjelaskan pengertian kebijakan negara atau pemerintah seperti yang dikutip oleh Islamy (2003:18) dalam bukunya Prinsip-Prinsip Perumusan Kebijaksanaan Negara bahwa "Kebijakan negara adalah apapun yang dipilih oleh pemerintah untuk dilakukan atau tidak dilakukan."Hanry merumuskan pengertian kebijakan negara seperti yang dikutip oleh Islamy (2003:52) dalam bukunya Prinsip-Prinsip Perumusan Kebijaksanaan Negara, sebagai berikut : Kebijakan negara itu seharusnya dibuat oleh lembaga pemerintah atau bagaimakah unsur-unsur dalam proses konversi yang berfungsi mengubah masukan-masukan dari lingkungan menjadi keluaran-keluaran yang seharusnya diatur secara optimal. Jenkins merumuskan kebijakan negara seperti yang dikutip oleh Wahab (2008:4) dalam bukunya Analisis Kebijaksanaan dari Formulasi ke Implementasi Kebijaksanaan Negara sebagai berikut : Kebijakan Negara adalah serangkaian keputusan yang saling berkaitan yang diambil oleh seorang aktor politik atau sekelompok aktor politik berkenaan dengan tujuan yang telah dipilih beserta cara-cara untuk mencapainya dalam suatu situasi dimana keputusankeputusan itu prinsipnya masih berada dalam batas-batas kewenangan kekuasaan dari para aktor tersebut.

\section{Kompetensi SDM}

Kompetensi adalah suatu kemampuan yang dilandasi oleh keterampilan dan pengetahuan yang didukung oleh sikap kerja serta penerapannya dalam melaksanakan tugas dan pekerjaaan di tempat kerja yang mengacu pada persyaratan kerja yang di tetapkan. Sutrisno (2010:221). Mc Clelland (dalam Sudarmanto, 2009:48) menyatakan kompetensi adalah karakteristik dasar personal yang menjadi faktor penentu sukses tidaknya seseorang dalam mengerjakan suatu pekerjaan atau situasi. Kompetensi adalah suatu kemampuan untuk melaksanakan atau melakukan suatu pekerjaan atau tugas yang dilandasi atas keterampilan dan pengetahuan serta didukung oleh sikap kerja yang dituntut oleh pekerjaan tersebut. Dengan demikian, kompetensi menunjukkan keterampilan atau pengetahuan yang dicirikan oleh profesionalisme dalam bidang tertentu sebagai sesuatu yang terpenting, sebagai unggulan di bidang tersebut. Menurut Alwi (2006: 6) "Sumber Daya Manusia atau human resource adalah orang yang bekerja dalam suatu organisasi yang sering pula disebut karyawan atau pegawai".

Sedangkan menurut Nawawi (2001:57) sumber daya manusia adalah manusia atau orang yang bekerja atau menjadi anggota suatu organisasi yang disebut personil, pegawai, karyawan, tenaga kerja, dll. Menurut Mangkunegara (2005:40) kompetensi sumber daya manusia adalah kompetensi yang 
berhubungan dengan pengetahuan, keterampilan, kemampuan, dan karakteristik kepribadian yang mempengaruhi secara langsung terhadap kinerjanya. Dengan demikian dapat disimpulkan bahwa kompetensi sumber daya manusia adalah suatu yang dapat memberikan gambaran tentang kemampuan suatu individu sumber daya manusia untuk melaksanakan tugas tertentu. Kompetensi sumber daya manusia juga dapat diartikan sebagai karakteristik dasar individu yang dalam hubungan sebab akibat berkaitan dengan performa yang efektif atau superior dalam suatu pekerjaan atau jabatan.

\section{Efektivitas Pengelolaan Sampah.}

Menurut Steers (dalam Sutrisno 2011:23), pada umumnya efektivitas hanya dikaitkan dengan tujuan organisasi, yaitu laba, yang cenderung mengabaikan aspek terpenting dari keseluruhan prosesnya, yaitu sumber daya manusia. Robbins (dalam Indrawijaya 2010:175) efektivitas dapat didefinisikan sebagai tingkat pencapaian organisasi atas tujuan jangka pendek (tujuan) dan jangka panjang (cara). Pemilihan itu mencerminkan konstituensi strategis, minat mengevaluasi, dan tingkat kehidupan organisasi. Siagian (dalam Indrawijaya 2010:175) , memberikan pengertian tentang efektivitas berkaitan dengan pelaksanaan suatu pekerjaan, yaitu; "Penyelesaian perkerjaan tepat pada waktu yang telah ditetapkan. Artinya apakah pelaksanaan suatu tugas dinilai baik atau tidak, terutama menjawab pertanyaan bagaimana cara melaksanakannya, dan berapa biaya yang dikeluarkan untuk itu."Saxena (dalam Indrawijaya 2010:176)

Efektivitas adalah suatu ukuran yang menyatakan seberapa jauh target (kualitas, kuantitas, waktu) telah dicapai. Makin besar target yang dicapai, maka semakin tinggi tingkat efektivitas. Konsep ini orientasinya lebih tertuju pada keluaran. Masalah penggunaan masukan tidak menjadi isu dalam konsep ini. Pada umumnya organisasi pemerintah (yang tidak mencari laba) berorientasi ke pencapaian efektivitas." Menurut Stoner (dalam Darsono \& Siswandoko, Tjatjuk, 2011:196) menjelaskan efektivitas adalah konsep yang luas mencakup berbagai faktor di dalam maupun diluar organisasi dalam usaha untuk mencapai tujuan atau sasaran organisasi.

Menurut Reksosoebroto (1985) dalam Efrianof (2001) pengelolaan sampah sangat penting untuk mencapai kualitas lingkungan yang bersih dan sehat, dengan demikian sampah harus dikelola dengan sebaik-baiknya sedemikian rupa sehingga hal-hal yang negatif bagi kehidupan tidak sampai terjadi. Dalam ilmu kesehatan lingkungan, suatu pengelolaan sampah dianggap baik jika sampah tersebut tidak menjadi tempat berkembangbiaknya bibit penyakit serta sampah tersebut tidak menjadi media perantara menyebar luasnya suatu penyakit. Syarat lainnya yang harus terpenuhi dalam pengelolaan sampah ialah tidak mencemari udara, air, dan tanah, tidak menimbulkan bau (segi estetis), tidak menimbulkan kebakaran dan lain sebagainya.

23 Available online at website :http://journal.uta45jakarta.ac.id/index.php/admpublik/index Copyright (C) 2017| IJPA | E-ISSN:2460-0369 


\section{Kerangka Pemikiran}

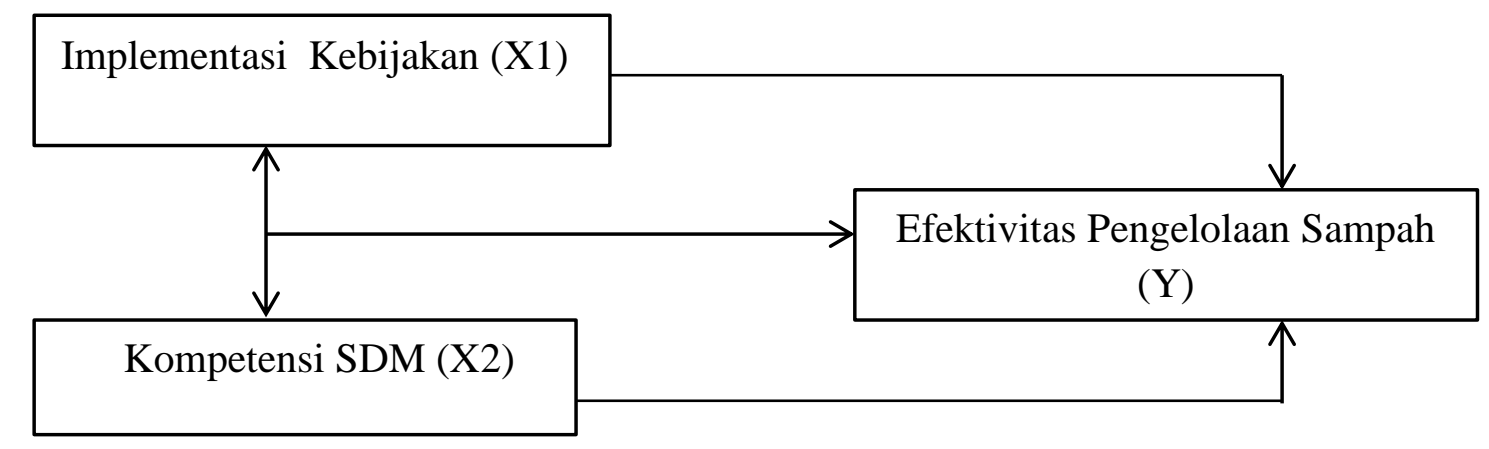

Gambar 1 : Kerangka Pemikiran

Hipotesis Penelitian. Adapun hipotesis dari penelitian ini adalah sebagai berikut :

H1 : Di duga ada pengaruh yang postif dan signifikan implementasi kebijakan terhadap efektivitas pengelolaan sampah di Kota Depok.

H2 : Di duga ada pengaruh yang postif dan signifikan kompetensi SDM terhadap efektivitas pengelolaan sampah di Kota Depok.

H3 : Di duga ada pengaruh yang postif dan signifikan implementasi kebijakan dan kompetensi SDM secara simultan terhadap efektivitas pengelolaan sampah di Kota Depok.

\section{METODE PENELTIAN}

\section{Jenis Penelitian}

Penelitian ini adalah penelitian yang bersifat deskriptif kuantitatif yang bertujuan untuk mengetahui variabel-variabel apa saja yang mempengaruhi efektivitas pengelolaan sampah di Kota Depok.

\section{Jenis Dan Metode Pengumpulan Data}

Metode pengumpulan data adalah menggunakan data primer yang diperoleh dari penyebaran kuesioner. Data primer digunakan untuk mengukur variabel penelitian. Data primer diperoleh melalui survey dengan mengisi kuesioner yang diberikan secara langsung kepada responden yang bersangkutan. Dalam melaksanakan pengumpulan data dan informasi yang diperlukan sebagai dasar untuk penulisan penelitian,peneliti membuat kuesioner yang berisikan pertanyaan dari masing-masing variabel. Dari hasil jawaban responden diukur dengan menggunakan skala likert dengan alternative 5 (lima) jawaban, yaitu: Sangat Setuju (SS) di beri skor 5,Setuju (S) di beri skor 4, Netral (N) di beri skor 3, Tidak Setuju (TS) di beri skor 2, dan Sangat Tidak Setuju (STS) diberi skor 1. 


\section{Populasi dan Sampel}

Menurut Sugiyono (2012:90) mengemukakan populasi adalah wilayah generalisasi yang terdiri atas obyek/subyek yang mempunyai kualitas dan karakteristik tertentu yang ditetapkan oleh peneliti untuk dipelajari dan kemudian ditarik kesimpulan. Tujuan diadakannya populasi ialah agar kita dapat menentukan besarnya anggota sampel yang akan diambil dari anggota populasi dan membatasi berlakunya daerah generalisasi.Adapun populasi yang akan diteliti dalam penelitian ini adalah seluruh pegawai Negeri Sipil (PNS) Dinas Kebersihan Kota Depok yang berjumlah 60 orang. Menurut Sugiyono (2012:56) mengemukakan bahwa sampel adalah sebagian dari jumlah dan karakteristik yang dimiliki oleh populasi tersebut. Teknik pengambilan sampel dalam penelitian ini adalah dengan teknik Nonprobability Sampling adalah teknik pengambilan sampel yang tidak memberi peluang/kesempatan sama bagi setiap unsur atau anggota populasi untuk dipilih menjadi sampel. Dengan demikian peneliti mengambil teknik Sampling Jenuh 60, teknik sampling jenuh adalah teknik penentuan sampel bila semua anggota populasi digunakan sebagai sampel. Hal ini sering dilakukan bila jumlah populasi relatif kecil, kurang dari 100 orang, atau penelitian yang ingin membuat generalisasi dengan kesalahan yang sangat kecil. Istilah lain sampel jenuh adalah sensus, dimana semua anggota populasi dijadikan sampel, Sugiyono (2012:96) karena populasi yang didapatkan oleh peneliti yaitu 60 orang maka peneliti pemilih semua populasi menjadi sampel.

\section{Variabel Penelitian}

Dalam penelitian ini terdapat 3 (tiga) variabel yang terdiri dari 2 (dua) variabel independen dan 1 (satu) variabel dependen. Variabel independen dalam penelitian ini adalah implementasi kebijakan yaitu cara agar sebuah kebijakan dapat mencapai tujuannya.Kompetensi SDM adalah sebagai karakteristik dasar individu yang dalam hubungan sebab akibat berkaitan dengan performa yang efektif atau superior dalam suatu pekerjaan atau jabatan. Variabel Dependen dalam penelitian ini adalah efektivitas pengelolaan sampah yaitu Penyelesaian perkerjaan pengelolaan sampah tepat pada waktu yang telah ditetapkan.

\section{Teknik Analisa Data}

Uji coba instrumen dalam penelitian menggunakan Uji Validitas dan Reliabilitas. Pengertian Validitas menurut Arikunto (2005) adalah suatu instrumen penelitian dapat dikatakan valid, bilamana dapat mengukur variabel yang diteliti secara tepat atau dengan kata lain ada kecocokan diantara apa yang diukur dengan tujuan pengukuran.Rumus yang dipergunakan untuk mengukur validitas adalah korelasi product moment dari Pearson yang dinyatakan sebagai berikut : 
$\mathrm{r}=\frac{\mathrm{n} \cdot \Sigma \mathrm{xy}-(\Sigma \mathrm{x})(\Sigma \mathrm{y})}{\sqrt{\left\{\mathrm{n} \cdot \Sigma \mathrm{x}^{2}-(\Sigma \mathrm{x})^{2}\right\}\left\{\mathrm{n} \cdot \Sigma \mathrm{y}^{2}-(\Sigma \mathrm{y})^{2}\right\}}}$

Dimana :

$\mathrm{n}$ = Banyaknya Pasangan data $\mathrm{X}$ dan $\mathrm{Y}$

$\Sigma \mathrm{x}=$ Total Jumlah dari Variabel $\mathrm{X}$

$\Sigma y=$ Total Jumlah dari Variabel Y

$\Sigma \mathrm{X}^{2}=$ Kuadrat dari Total Jumlah Variabel X

$\Sigma \mathrm{y}^{2}=$ Kuadrat dari Total Jumlah Variabel Y

$\Sigma x y=$ Hasil Perkalian dari Total Jumlah Variabel X dan Variabel Y

Kaidah pengambilan kesimpulan sebagai berikut :

Jika $r$ hitung $>r$ table, maka instrumen mempunyai validitas yang tinggi .

Jika $\mathrm{r}$ hitung $<\mathrm{r}$ table, maka instrumen itu untuk faktor tertentu tidak valid.

Pengujian Reliabilitas adalah sebuah instrumen dapat mengukur suatu yang diukur secara konsisten dari waktu ke waktu. Konsep reliabilitas yang digunakan dalam penelitian ini adalah reliabilitas konsistensi internal (internal consistency realibility). Pengujian terhadap konsistensi keterkaitan diantara butir-butir pertanyaan dalam penelitian ini instrument yang dimaksud adalah kuisioner. Peneliti hanya memerlukan sekali melakukan pengujian dengan menggunakan teknik statistic tertentu terhadap skor jawaban responden yang dihasilkan dari penggunaan instrument yang bersangkutan. Rumus reliabilitas yang digunakan adalah formulasi Alpha Cronchbach sebagai berikut:

$$
\alpha=\left(\frac{K}{K-1}\right)\left(\frac{s_{r}^{2}-\Sigma s_{i}^{2}}{s_{x}^{2}}\right)
$$

Dimana :

$$
\begin{array}{ll}
\alpha & =\text { Koefisien reliabilitas Alpha Cronbach } \\
K & =\text { Jumlah item pertanyaan yang diuji } \\
\Sigma s_{i}^{2} & =\text { Jumlah varians skor item } \\
S X^{2} & =\text { Varians skor-skor tes (seluruh item K) }
\end{array}
$$

\section{HASIL PENELITIAN DAN PEMBAHASAN Pengujian Validitas dan Reliabilitas Instrumen}

26 Available online at website :http://journal.uta45jakarta.ac.id/index.php/admpublik/index Copyright (C) 2017| IJPA | E-ISSN:2460-0369 
Adapun dalam penelitian ini untuk menguji validitas menggunakan korelasi Prodet moment dari Pearson. Berdasarkan hasil penelitian dan pengelohan data pengujian hipotesis dapat dilihat pada tabel di bawah ini :

Tabel 1. Uji Hipotesis Ke-1 (H1) Variabel Implementasi Kebijakan (X1) Terhadap

Efektivitas Penglolaan Sampah (Y)

Coefficients $^{\mathrm{a}}$

\begin{tabular}{|c|c|c|c|c|c|c|}
\hline \multirow{2}{*}{\multicolumn{2}{|c|}{ Model }} & \multicolumn{2}{|c|}{ Unstandardized Coefficients } & $\begin{array}{c}\text { Standardized } \\
\text { Coefficients }\end{array}$ & \multirow[b]{2}{*}{$t$} & \multirow[b]{2}{*}{ Sig. } \\
\hline & & $B$ & Std. Error & Beta & & \\
\hline 1 & (Constant) & 9.758 & 2.517 & & 3.876 & .000 \\
\hline & Implementasi Kebijakan & .963 & .080 & .844 & 11.990 & .000 \\
\hline
\end{tabular}

a. Dependent Variable: Efektivitas

Penglolaan Sampah (Y)

Berdasarkan hasil analisis dengan menggunakan program SPSS menunjukkan hasil bahwa koefisien regresi sebesar 0,963 nilai konstanta sebesar 9,758 hal ini menunjukkan bahwa apabila variabel implementasi kebijakan tidak ada $\left(\mathrm{X}_{1}=0\right)$, maka variabel implementasi kebijakansebesar 0,963 dan efektivitas pengelolaan sampah di pengeruhi oleh implementasi kebijakan sebesar 0,963 Setelah nilai koefisien regresi dan nilai kontanta diketahui, maka model regresi linier adalah Y $=9,758+0,963 X_{1}$. Selanjutnya nilai $t_{\text {hitung }}$ implementasi kebijakan sebesar 11,990 dengan signifikan $t$ bernilai 0,000 sedangkan nilai $t_{\text {tabel }}$ sebesar 1,67, karena nilai $\mathrm{t}_{\text {hitung }}=11,990>\mathrm{t}_{\text {tabel }}=1,67$ atau 0,000 $<0,05$ maka Ho ditolak dan Ha diterima, dengan demikian maka hipotesis pertama (H1) dalam penelitian ini adalah implementasi kebijakan berpengaruh positif dan signifikan terhadap efektivitas pengelolaan sampah.

Tabel 2. Nilai Koefisien Determinasi Antara Variabel Implementasi Kebijakan (X1) Terhadap Efektivitas Pengelolaan Sampah (Y)

Model Summary

\begin{tabular}{|l|r|r|r|r|}
\hline Model & $R$ & $R$ Square & Adjusted $R$ Square & Std. Error of the Estimate \\
\hline 1 & $.844^{\mathrm{a}}$ & .713 & .708 & 2.17825 \\
\hline
\end{tabular}

a. Predictors: (Constant), Implementasi Kebijakan

Untuk menghitung Nilai Koefisien Determinsi secara manual dapat digunakan rumus : $\mathrm{R}^{2}=(\mathrm{r})^{2} \times 100 \%=0,713$ atau $71,3 \%$. Berdasarkan perhitungan di atas 
diperoleh nilai $(\mathrm{r})^{2}$ sebesar 0,713 atau $71,3 \%$ variabel efektivitas pengelolaan sampah yang terjadi disebabkan oleh implementasi kebijakan pada Kantor DKP Kota Depok. Dengan kata lain bahwa efektivitas pengelolaan sampah (Y) dipengaruh oleh variabel implementasi kebijakan (X1) sebesar 71,3\%, sedangkan sisanya 28,7 \% dipengaruhi oleh faktor lain yang dalam hal ini tidak diteliti oleh penulis.

Uji hipotesis ( $\mathrm{H} 2$ ) parsial atau sederhana variabel Kompetensi SDM terhadap variabel Efektifitas Pengelolaan Sampah di DKP Kota Depok dengan menggunakan perhitungan program SPSS dapat dilihat pada tabel 3 adalah sebagai berikut:

Tabel 3. Uji Hipotesis ke-2 (H2) Variabel Kompetensi SDM $\left(\mathrm{X}_{2}\right)$ Terhadap Efektivitas Pengelolaan Sampah (Y)

Coefficients $^{\mathrm{a}}$

\begin{tabular}{|c|c|c|c|c|c|c|}
\hline \multirow{2}{*}{\multicolumn{2}{|c|}{ Model }} & \multicolumn{2}{|c|}{ Unstandardized Coefficients } & \multirow{2}{*}{$\begin{array}{c}\begin{array}{c}\text { Standardized } \\
\text { Coefficients }\end{array} \\
\text { Beta }\end{array}$} & \multirow[b]{2}{*}{$t$} & \multirow[b]{2}{*}{ Sig. } \\
\hline & & $B$ & Std. Error & & & \\
\hline 1 & (Constant) & 12.613 & 3.264 & & 3.864 & .000 \\
\hline & Kompetensi SDM & .874 & .104 & .739 & 8.362 & .000 \\
\hline
\end{tabular}

a. Dependent Variabel : Efektivitas Pengelolaan

Sampah

Berdasarkan perhitungan pada tabel 3 menunjukkan hasil bahwa nilai koefisien regresi sebesar 0,874 dan nilai konstanta sebesar 12,613, hal ini menunjukkan bahwa apabila variabel kompetensi SDM tidak ada $\left(X_{2}=0\right)$, maka variabel Kompetensi SDM sebesar 12,613 dan efektivitas pengelolaan sampah di pengeruhi oleh kompetensi SDM sebesar 0,874. Setelah nilai koefisien regresi dan nilai kontanta diketahui maka model regresi linier adalah $\mathrm{Y}=12.613+$ $0,874 \mathrm{X}_{2}$. Selanjutnya hasil pengujian hipotesis sebagai berikut : Hipotesis (H2) menyatakan bahwa Kompetensi SDM berpengaruh positif dan signifikan terhadap Efektivitas Pengelolaan Sampah, hal ini dapat dilihat dari hasil nilai $t_{\text {hitung }}$ sebesar 8,362, sedangkan nilai $t_{\text {tabel }}$ pada tingkat signifikan 95\% $(\alpha=0,05)$ sebesar 1,67 maka $t_{\text {hitung }}>t_{\text {tabel }}(\alpha=0,05)$, hasil analisis tersebut signifikan. Hal ini berarti hipotesis $(\mathrm{H} 2)$ yang diajukan dapat diterima karena variabel Kompetensi SDM berpengaruh positif dan signifikan terhadap Efektivitas Pengelolaan Sampah di dalam regresi. Dengan kata lain Kompetensi SDM berpengaruh positif dan signifikan terhadap Efektivitas Pengelolaan Sampah 
Tabel 4. Nilai Koefisien Determinasi Antara Variabel Kompetensi SDM (X2) Terhadap Efektivitas Pengelolaan Sampah (Y)

\begin{tabular}{|l|r|r|r|r|}
\hline \multicolumn{6}{|c|}{ Model Summary } \\
\hline 1 & \multicolumn{1}{|c|}{$R$} & R Square & Adjusted $R$ Square & Std. Error of the Estimate \\
\hline 1 & $.739^{\mathrm{a}}$ & .547 & .539 & 2.73550 \\
\hline
\end{tabular}

a. Predictors: (Constant), Kompetensi SDM

Untuk menghitung Nilai Koefisien Determinsi secara manual dapat digunakan rumus : $\mathrm{R}^{2}=(\mathrm{r})^{2} \times 100 \%=0,547$ atau $54,7 \%$. Berdasarkan perhitungan diatas diperoleh nilai $(\mathrm{r})^{2}$ sebesar 0,547 atau 54,7 \% variabel Efektivitas Pengelolaan Sampah yang terjadi disebabkan oleh Kompetensi SDM pada Kantor DKP Kota Depok. Dengan kata lain bahwa pengaruh variabel Kompetensi SDM (X2) terhadap Efektivitas Pengelolaan Sampah (Y) pada Kantor DKP Kota Depok sebesar 54,7 \%, sedangkan sisanya 45,3 \% dipengaruhi oleh faktor lain yang dalam hal ini tidak diteliti oleh penulis.

Uji Hipotesis (H3) secara simultan Antara Variabel Implementasi Kebijakan ( $\mathrm{X}_{1}$ ) dan Kompetensi SDM $\left(\mathrm{X}_{2}\right)$ Terhadap Efektivitas Pengelolaan Sampah (Y)

Uji hipotesis (H3) atau Uji F variabel Implementasi Kebijakan dan Kompetensi SDM secara simultan terhadap variabel efektivitas Pengelolaan Sampah pada dasarnya menunjukkan apakah variabel independen yang dimasukkan dalam model mempunyai pengaruh secara simultan terhadap variabel dependen. Dengan menggunakan perhitungan program SPSS dapat dilihat pada tabel 5 adalah sebagai berikut:

Tabel 5. Uji Hipotesis Ke-3 (H3) secara simultan Antara Variabel Implementasi Kebijakan $\left(\mathrm{X}_{1}\right)$ dan Kompetensi SDM $\left(\mathrm{X}_{2}\right)$ Terhadap Efektivitas Pengelolaan Sampah (Y)

ANOVA $^{b}$

\begin{tabular}{|ll|r|r|r|c|c|}
\hline \multicolumn{2}{|l|}{ Model } & Sum of Squares & Df & Mean Square & \multicolumn{1}{c|}{$F$} & \multicolumn{1}{c|}{ Sig. } \\
\hline $1 \quad$ Regression & 685.435 & 2 & 342.717 & 71.868 & $.000^{2}$ \\
& Residual & 271.815 & 57 & 4.769 & & \\
\hline
\end{tabular}




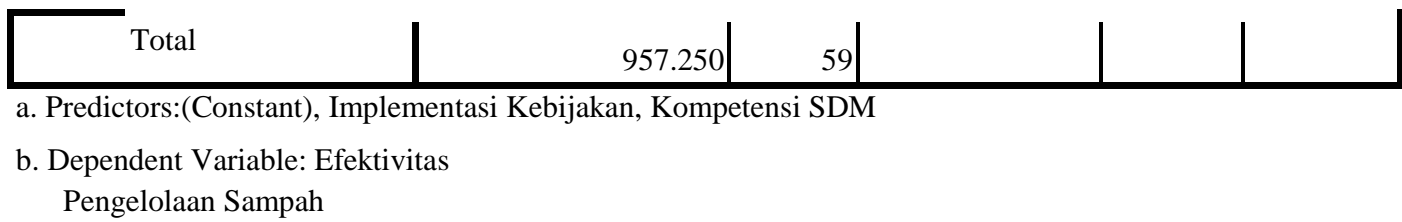

Hasil pengujian hipotesis pada table 5 di atas adalah sebagai berikut: Hipotesis (H3) menyatakan bahwa Implementasi Kebijakan dan Kompetensi SDM berpengaruh positif dan signifikan terhadap Efektivitas Pengelolaan Sampah, hal ini dapat dilihat hasil perhitungan nilai $\mathrm{F}_{\text {hitung }}$ sebesar 71,868 , sedangkan nilai $\mathrm{F}_{\text {tabel }}$ pada tingkat signifikan $95 \%(\alpha=0,05)$ sebesar 3,15 maka dapat dikatakan bahwa nilai $\mathrm{F}_{\text {hitung }}>\mathrm{F}_{\text {tabel }}(\alpha=0,05)$ dan hasil analisis tersebut signifikan. Hal ini berarti hipotesis (H3) yang diajukan dapat diterima karena variabel Implementasi Kebijakan dan Kompetensi SDM secara simultan atau bersama-sama berpengaruh positif dan signifikan terhadap Efektivitas Pengelolaan Sampah di dalam regresi. Dengan kata lain Implementasi Kebijakan dan Kompetensi SDM berpengaruh positif dan signifikan terhadap Efektivitas Pengelolaan Sampah di Kota Depok.

Tabel 6. Uji Hipotesis (H3) secara simultan Antara Variabel Implementasi

Kebijakan $\left(\mathrm{X}_{1}\right)$ dan Kompetensi SDM $\left(\mathrm{X}_{2}\right)$ Terhadap Efektivitas Pengelolaan Sampah (Y)

Coefficients $^{\mathrm{a}}$

\begin{tabular}{|c|c|c|c|c|c|c|}
\hline \multirow{2}{*}{\multicolumn{2}{|c|}{ Model }} & \multicolumn{2}{|c|}{ Unstandardized Coefficients } & \multirow{2}{*}{$\begin{array}{c}\begin{array}{c}\text { Standardized } \\
\text { Coefficients }\end{array} \\
\text { Beta }\end{array}$} & \multirow[b]{2}{*}{$\mathrm{t}$} & \multirow[b]{2}{*}{ Sig. } \\
\hline & & B & Std. Error & & & \\
\hline 1 & (Constant) & 9.002 & 2.679 & & 3.361 & .00 \\
\hline & $\begin{array}{l}\text { Implementasi } \\
\text { Kebijakan }\end{array}$ & .859 & .147 & .753 & 5.832 & .0 \\
\hline & Kompetensi SDM & .128 & .153 & .109 & .842 & .403 \\
\hline
\end{tabular}

a. Dependent Variable: Efektifitas Pengelolaan

Sampah

Berdasarkan perhitungan pada tabel 6 di atas menunjukkan hasil bahwa nilai koefisien regresi untuk variabel Implementasi Kebijakan sebesar 0,859, sedangkan nilai koefisien regresi untuk variabel Kompetensi SDM sebesar 0,128 dan nilai konstanta sebesar 9,002, hal ini menunjukkan bahwa apabila variabel Implementasi Kebijakan dan Kompetensi SDM tidak ada $\left(\mathrm{X}_{1}\right.$ dan $\left.\mathrm{X}_{2}=0\right)$, maka variabel Efektivitas Pengelolaan Sampah sebesar 9,002, hal ini secara simultan Efektivitas Pengelolaan Sampah dipengeruhi oleh variabel Implementasi Kebijakan sebesar 0,859 dan variabel Kompetensi SDM sebesar 0,128. Setelah 
nilai koefisien regresi dan nilai konstanta diketahui maka model regresi linier berganda adalah $\mathrm{Y}=9,002+0,859 \mathrm{X}_{1}+0,128 \mathrm{X}_{2}$

Tabel 7. Uji Koefisien Determinasi Antara Variabel Implementasi Kebijakan (X1 ) dan Kompetensi SDM (X2) Terhadap Efektivitas Pengelolaan Sampah (Y). Dari data yang telah dikumpulkan selama penelitian dan diolah dengan menggunakan statistik regresi berganda dengan program SPSS. Nilai uji koefisien determinasi dapat dilihat pada tabel 7 berikut ini :

Model Summary

\begin{tabular}{|l|r|r|r|r|}
\hline Model & $R$ & $R$ Square & Adjusted $R$ Square & Std. Error of the Estimate \\
\hline 1 & .846 & .716 & .706 & 2.18373 \\
\hline
\end{tabular}

a. Predictors: (Constant), Implementasi Kebijakan, Kompetensi SDM

Dari hasil analisis statistik dengan menggunakan program SPSS diperoleh nilai Adjusted $R$ Square sebesar 0,706, hal ini berarti 70,6\% efektivitas pengelolaan sampah dapat dijelaskan oleh variasi dari kedua variabel independen ( Implementasi kebijakan dan kompetensi SDM). Sedangkan sisanya $29,4 \%$ dipengaruhi oleh faktor-faktor lain di luar penelitian ini.

\section{Kesimpulan}

Berdasarkan uraian dan pembahasan pada bab sebelumnya, maka penulis dapat memberikan kesimpulan adalah sebagai berikut :

1. Berdasarkan hasil analisis yang penulis lakukan diketahui bahwa Implementasi Kebijakan (X1) berpengaruh positif dan signifikan terhadap Efektivitas Pengelolaan Sampah, (Y), hal tersebut dapat dilihat dari hasil uji hipotesis yang diperoleh hasil $t_{\text {hitung }}>t_{\text {tabel }}(11,990>1,67)$, maka Ho ditolak, artinya secara parsial terdapat yang signifikan antara Implementasi Kebijakan (X1) terhadap Efektivitas Pengelolaan Sampah (Y) di Kota Depok. Sedangkan berdasarkan hasil analisa koefisien determinasi diperoleh hasil sebesar 0,713 atau 71,3\%, variabel efektivitas pengelolaan sampah yang terjadi disebabkan oleh implementasi kebijakan pada Kantor DKP Kota Depok. Dengan kata lain bahwa efektivitas pengelolaan sampah (Y) dipengaruh oleh variabel implementasi kebijakan (X1) sebesar $71,3 \%$, sedangkan sisanya $28,7 \%$ dipengaruhi oleh faktor lain yang dalam hal ini tidak diteliti oleh penulis.

2. Berdasarkan hasil analisis yang telah lakukan diketahui bahwa Kompetensi SDM berpengaruh positif dan signifikan terhadap Efektivitas Pengelolaan Sampah, hal ini terbukti dari hasil uji hipotesis yang diperoleh hasil $t$ hitung $>\mathrm{t}$ tabel $(8,362>1,67)$, maka Ho ditolak, artinya secara parsial terdapat pengaruh yang signifikan antara Kompetensi SDM 
terhadap Efektivitas Pengelolaan Sampah di Kota Depok. Sedangkan berdasarkan hasil analisa koefisien determinasi diperoleh hasil sebesar 0,547 atau 54,7 \% variabel Efektivitas Pengelolaan Sampah yang terjadi disebabkan oleh Kompetensi SDM di Kantor DKP Kota Depok. Dengan kata lain bahwa pengaruh variabel Kompetensi SDM (X2) terhadap Efektivitas Pengelolaan Sampah (Y) pada Kantor DKP Kota Depok sebesar 54,7 \%, sedangkan sisanya 45,3 \% dipengaruhi oleh faktor lain yang dalam hal ini tidak diteliti oleh penulis.

3. Berdasarkan hasil analisis yang telah dilakukan diketahui bahwa Implementasi Kebijakan (X1) dan Kompetensi SDM (X2) berpengaruh positif dan signifikan terhadap Efektivitas Pengelolaan Sampah (Y), hal ini terbukti dari hasil uji F yang digunakan untuk mengetahui apakah dalam model regresi variabel Implementasi Kebijakan (X1) dan variabel Kompetensi SDM (X2) secara simultan atau bersama-sama berpengaruh positif dan sinifikan terhadap variabel Efektivitas Pengelolaan Sampah (Y). yang diperloleh nilai $\mathrm{F}_{\text {hitung }} 71,868$, Sedangkan harga kritis nilai $\mathrm{F}$ tabel pada tingkat kepercayaan $95 \%((\alpha=0,05)$ sebesar 3,15. Dengan demikian $\mathrm{F}_{\text {hitung }}>\mathrm{F}_{\text {tabel, }}$ Sehingga jelas bahwa Ho ditolak dan Ha diterima. Hal ini menunjukkan bahwa secara silmultan Implementasi Kebijakan (X1) dan Kompetensi SDM (X2) berpengaruh positif dan signifikan terhadap Efektivitas Pengelolaan Sampah (Y) di Kota Depok. Sedangkan berdasarkan hasil analisa koefisien determinasi diperoleh hasil sebesar 0,706 atau 70,6 \% variabel Efektivitas Pengelolaan Sampah (Y) yang terjadi disebabkan oleh Implementasi Kebijakan (X1) dan Kompetensi SDM (X2) di Kantor DKP Kota Depok. Dengan kata lain bahwa pengaruh variabel Implementasi Kebijakan (X1) dan Kompetensi SDM (X2) terhadap Efektivitas Pengelolaan Sampah (Y) pada Kantor DKP Kota Depok sebesar 70,6\%, sedangkan sisanya 29,4 \% dipengaruhi oleh faktor lain yang dalam hal ini tidak diteliti oleh penulis.

\section{Saran}

1. Sebaiknya Kontor Dinas Kebersihan dan Pertamanan Kota Depok diharapkan mampu dan bisa memberikan pelayanan sejalan dengan tingkat tuntutan dan perkembangan kemajuan masyarakat Kota Depok dan mampu pula memotivasi warga kota untuk berperan serta secara aktif menjadikan cara pandang hidup masyarakat dalam keseharian bahwa kebersihan harus menjadi tanggungjawab bersama semua pihak, baik pemerintah daerah maupun warga masyarakat itu sendiri. 
2. Sebaiknya untuk meningkatkan kualitas pelayanan dalam bidang kebersihan dengan tersedianya sarana dan prasarana serta peralatan yang lebih modern

3. Sebaiknya menggali sumber pendapatan daerah dengan memberdayakan masyarakat berpartisipasi dalam kebersamaan dalam menangani permasalahan kebersihan melalui dukungan dana yang diberikan melalui pembayaran retribusi kebersihan.

4. Sebaiknya merubah pola pelayanan dalam penanganan pengelolaan pelayanan kebersihan dari yang bersifat konvensional ke pelayanan yang bersifat modern.

5. Sebaiknya DKP Kota Depok dengan kewenangannya harus mampu merubah pola pandang masyarakat terhadap kebersihan dari yang tadinya memandang kebersihan itu dianggap sebagai beban menjadi kebutuhan hidup keseharian dari masyarakat sehingga diharapkan persepsi masyarakat akan memandang bahwa kebersihan tersebut harus menjadi tanggungjawab bersama dari semua pihak.

\section{Daftar Pustaka}

Arikunto, Suharsimi. 2000. Prosedur penelitian; suatu pendekatan praktek edisi ke 3. Jakarta. Rineke Cipta

Dunn, William N., 2000, Pengantar Analisis Kebijakan Publik Edisi Kedua, Yogyakarta. Gajah Mada University Press

Islamy, Irfan. 2003. Prinsip-Prinsip Perumusan Kebijaksanaan Negara. Jakarta : Bumi Aksara.

Indrawijaya, I. 2000, Perilaku Organisasi, Sinar Baru Algensindo, Bandung.

Nugroho D, Riant. 2003. Kebijakan Publik Formulasi, Implementasi, Evaluasi. Jakarta:PT. Gramedia.

Nawawi, Hadari. 2006. Evaluasi dan Manajemen Kinerja di Lingkungan Perusahaan dan Industri. Yogyakarta: Gajah Mada University Press.

Sugiyono, 2005, Metode Penelitian Administrasi, Alfabeta, Bandung.

Samodra, et, al. 2003. Pengantar Analisis Kebijakan Publik. Jakarta : PT. Gunung Agung.

Sugiyono. 2012. Metode Penelitian Kuantitatif Kualitatif dan R\&B. Bandung: Alfabeta.

P. Siagian. 1997. Filsafat Administrasi. Jakarta : PT. Gunung Agung.

Peraturan Daerah Kota Depok No.5 Tahun 2014 tentang Pengelolaan Sampah

Sudarmanto, 2009. Kinerja dan Pengembangan Kompetensi SDM. Yogyakarta: Pustaka Pelajar

Winarno, Budi. 2008. Kebijakan Publik Teori dan Proses. Jakarta: PT Buku Kita 
Wahab, Solichin Abdul. 2002. Analisis Kebijaksanaan dari Formulasi ke Implemantasi Kebijaksanaan Negara. Jakarta : Bumi Aksara.

2008. Analisis Kebijaksanaan dari Formulasi ke Implemantasi Kebijaksanaan Negara. Jakarta : Bumi Aksara.

Winarno, Budi. 2002. Teori dan Proses Kebijakan Publik. Yogyakarta: Media Pressindo

Waldo, Dwigh. 1991. Public Administration. Jakarta: Bumi Aksara.

Winarno, Budi. 2002. Teori dan Proses Kebijakan Publik. Jakarta : Erlangga.

Robbins, S.P. 2003, Perilaku Organisasi, Jilid 1: PT INDEKS Kelompok Gramedia, Jakarta. 